Check for updates

The BMJ

Cite this as: BMJ 2022;376:096 http://dx.doi.org/10.1136/bmj.096 Published: 13 January 2022

\title{
Covid-19: Government's use of VIP lane for awarding PPE contracts was unlawful, says judge
}

Clare Dyer

UK government action in giving priority treatment to suppliers of personal protective equipment (PPE) who were referred by MPs, ministers, or civil servants at the height of the covid-19 pandemic was unlawful, a High Court judge has ruled.

As the country was swept up in the pandemic without adequate supplies of PPE, the government established a high priority "VIP lane" through which potential suppliers with such contacts could gain quicker access to the contracts process.

The non-profit Good Law Project and the doctors' campaign group EveryDoctor challenged the award of PPE contracts worth hundreds of millions of pounds through the VIP lane to the pest control company PestFix and the family capital company Ayanda.

Mrs Justice O'Farrell ruled that it was unlawful for companies to be given preferential treatment on the basis of their allocation to the high priority lane, which was in breach of the European Union principle of equal treatment.

But she said the government had not placed any reliance on their referral to the lane when awarding the contracts to PestFix and Ayanda, which would have been granted in any event on their merits. Even if they had not been allocated to the lane, they would still have been given priority because of the substantial amounts of PPE they could supply which was urgently needed, she said.

In the circumstances, including that the contracts had already been performed or were expired, she refused to make the usual formal declaration that the conduct was unlawful, adding that it was sufficient that the illegality was marked by her judgment.

She noted, however, that many of the masks and other PPE supplied by the two companies were not suitable for NHS use, resulting in the waste of millions of pounds of taxpayers' money.

The Good Law Project and EveryDoctor said they were considering the implications of the judgment and the next steps.

Jo Maugham, Good Law Project’s director, said, “Good Law Project revealed the VIP lane for those with political connections in October 2020. And the court has now held that, unsurprisingly, the lane was illegal. Never again should any government treat a public health crisis as an opportunity to enrich its associates and donors at public expense.”

EveryDoctor's chief executive Julia Patterson, said, "We brought the government to court because NHS staff and other essential workers were woefully unsupported and unprotected by this government.
Many were provided with no PPE, and many died. The government must never again be allowed to conduct themselves in this manner during a national healthcare crisis."

A Department for Health and Social Care spokesman said, "The ruling says it is highly likely these offers would have been awarded if they were processed through other channels. All contracts underwent sufficient financial and technical due diligence and the court found that we did not rely on referral to the high priority lane when awarding contracts.

"Throughout the pandemic our absolute priority has always been saving lives and we have been working tirelessly to deliver PPE to protect our health and social care staff, with over 17.5 billion PPE items delivered so far.”

\section{R on the application of Good Law Project Limited and EveryDoctor $v$ Secretary of State for Health and Social Care. [2022] EWHC 46 (TCC). www.bailii.org/ew/cases/EWHC/TCC/2022/46.html}

This article is made freely available for personal use in accordance with BMJ's website terms and conditions for the duration of the covid-19 pandemic or until otherwise determined by BMJ. You may download and print the article for any lawful, non-commercial purpose (including text and data mining) provided that all copyright notices and trade marks are retained. 